\title{
GOODS AND SERVICES TAX (GST): CHALLENGES FACED BY BUSINESS OPERATORS IN MALAYSIA
}

\author{
Loo Ern Chen*, Mohd Shukry Bin Md Taib ${ }^{1}$

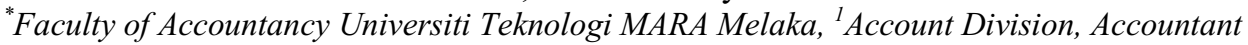 \\ General's Department of Malaysia
}

\begin{abstract}
The objective of this study is to identify the factors affecting business operators' awareness on the implementation of Goods and Services Tax (GST) and the perceived issues and problems they may likely encounter with the implementation of GST in Malaysia. Questionnaires were distributed to 302 registered members (business operators) of three Chambers of Commerce in Melaka. The findings of this study show that more than $70 \%$ of the respondents are aware of the GST mechanism and issues. The majority of the respondents also agreed that to comply with GST legislations, business operators need to have sufficient knowledge on appropriate and adequate documentation thus leading to increased compliance costs.
\end{abstract}

Keywords: Goods and Services Tax, awareness, compliance costs

\section{INTRODUCTION}

Goods and Services Tax (GST), also known as Value Added Tax (VAT) is a form of expenditure or consumption tax. Prior to the implementation of GST, among the expenditure taxes in force were the Sales $\operatorname{Tax}^{1}$ and Service Tax. ${ }^{2}$ Sales Tax, a single stage tax was imposed on goods manufactured in or imported into Malaysia. Service Tax, also a single stage tax was imposed on taxable services provided by taxable persons.

In the 2005 Budget Speech, it was announced that GST would be introduced, effective from 1 January 2007, but in 2006, the Government deferred GST implementation indefinitely. In the 2010 Budget Speech, the Minister of Finance announced the readiness of the Government to implement GST, and finally the Goods and Services Tax Act 2014 came into force effective from 1 April 2015, ${ }^{3}$ replacing the Sales and Service Tax (SST). The initial announcement and subsequent deferment on the implementation of GST was partly to give more time to business operators to change their business processes, to develop software and to provide training to their personnel pertaining to compliance with the GST legislations, ${ }^{4}$ and mechanism. ${ }^{5}$

\footnotetext{
${ }^{1}$ Sales Tax was imposed under the Sales Tax Act 1972.

2 Service Tax was imposed under the Service Tax Act 1975.

${ }^{3}$ GST is imposed under the Goods and Services Tax Act 2014.

${ }^{4}$ GST legislations comprise of the Goods and Services Tax Act 2014, Goods and Services Tax Regulations 2014, the various gazetted GST Orders (all of which have legal effects).
} 
GST is a multi-stage tax, imposed on the value added to goods or services in the production and distribution chain, and the tax is effectively on the increase in the value or price of goods or services as they pass through that chain.

${ }^{5}$ Generally, the operations of GST mechanism may be guided by the multitude of GST guidelines and the numerous DG Decisions.

[Type here] 
Generally, under the GST legislations, ${ }^{6}$ upon achieving the specific threshold ${ }^{7}$ from making taxable supplies, ${ }^{8}$ a business operator is liable to be registered as a taxable person (aka GST registrant). Since GST is to be collected at various stages of the production and supply chain, a GST registrant is required to charge GST (output tax) ${ }^{9}$ on taxable supplies made to its customers. Generally, a taxable supply is taxed at either standard rate ${ }^{10}$ or zero rate. ${ }^{11}$ For a taxable person, any GST paid is referred to as input tax. ${ }^{12}$ A taxable supply will go through a few processes or supply chain before it reaches the final consumer. Suppliers (who are taxable persons) along the supply chain will pay GST when they acquire input and will collect GST from customers on their output at the time of making supply. Suppliers (who are taxable persons) can set off their input $\operatorname{tax}^{13}$ against output tax and remit the net GST to Royal Malaysian Customs Department (RMCD).

Under the GST regime, GST registrants will need to manage documentation processes and keep all relevant records to account for input and output tax, which may be subject to audit by RMCD. GST registrants are required to keep business and accounting records related to GST for a period of seven years. These records can be kept either in Bahasa Melayu or English. The following are the list of records that should be kept by GST registrants:

(a) All records of goods or services supplied by or to a taxable person including tax invoices, statements of sales, receipts, credit notes, debit notes and export declaration forms;

(b) All records of importations of goods;

(c) Physical books of account, financial statements and paper based source documents including computer printouts of business and accounting records;

(d) Electronic records; and

(e) Details of accounting system, including charts, codes of accounts, instruction manuals, system and programmes documentation and specification, etc.

GST registrants are required to file their GST returns to RMCD not later than the last day of the following month after the end of a taxable period. Taxable period of a GST registrant depends on its taxable turnover. Those with annual gross taxable turnover of less than RM5 million are required to submit their tax returns quarterly. A monthly submission of tax return is applicable to those whose gross annual taxable turnover is more than RM5 million.

\footnotetext{
${ }^{6}$ Section 20, Goods and Services Tax Act 2014.

${ }^{7}$ The threshold is gross turnover of at least RM500,000 over a period of 12 months (or any period within less than 12 month) in relation to the supply of taxable goods or services. The RM500,000 threshold is only applicable to turnover of taxable supplies (i.e. standard rated supply and zero rated supply), but exclude turnover of exempt supplies.

${ }^{8}$ A 'taxable supply' means a supply of goods or services which are standard rated (i.e. 6\%) and zero-rated, but excludes exempt supply (Section 2(1), Goods and Services Tax Act 2014).

9 'Output tax' means tax on any taxable supply of goods or services made by a taxable person in the course or furtherance of its business in Malaysia (Section 2(1), Goods and Services Tax Act 2014).

10 The standard rate of $6 \%$ is gazetted under the Goods \& Services Tax (Rate of Tax) Order 2014.

11 The types of goods and services subjected to zero rate are gazetted under Goods \& Services Tax (Zero-Rated Supply) Order 2014.

12 'Input tax' means tax on any supply of goods or services (paid) to a taxable person; and tax paid or to be paid by a taxable person on the importation of goods, and the goods and services are used or to be used for the purposes of any business carried on or to be carried on by the taxable person [Section 2(1), Goods and Services Tax Act 2014].

${ }^{13}$ Claim of input tax credit is only allowable for making of 'taxable supply', which means that input tax in relation to exempt supply is not an allowable input tax credit.
} 


\section{Challenges faced by business operators}

Business operators, as intermediate parties need to be aware of, and be ready to accept that GST would impact on their business operations. Among the impacts is the GST charged on the acquisition of taxable supplies necessary for the operations of their businesses. Business operators would need to identify the GST paid that is allowable as input tax credit, as nonallowable input tax credit would lead to increase in cost of doing business.

Business operators could be facing challenges in identifying and distinguishing between taxable supplies (i.e. standard rated supply and zero rated supply) where input tax credit is allowable. The challenges is also in understanding the differences in making zero rated supplies and exempt supplies, ${ }^{14}$ as both do not attract any output tax, although input tax credit is allowable for the former, but not for the latter.

Awareness towards GST not only implies readiness of business operators for the implementation of GST, but also their potential acceptance and support for the GST regime. Business operators may not accept or support a change in the tax system unless they could recognise and are aware of the implications on their businesses. Feedback from business operators and the public is of utmost important in order to examine their readiness for the implementation of GST. By taking cognition of feedback from stakeholders, the relevant government agencies can then design appropriate plan and strategy for the implementation of GST.

With the implementation of GST, business operators need to change their accounting system and business processes and must be ready to institute proper accounting record keeping, train their personnel and have proper software to ensure successful documentation and recording for the purpose of GST compliance. Thus, there is possibility that business operators might face issues and problems pertaining to the compliance with GST legislations.

One importance aspect of the implementation of GST is whether business operators, who are GST registrants, as agents to collect tax understand GST issues and the mechanism as applied in Malaysia. To ensure a successful implementation of GST, business operators need to know when they are required to register, to determine the input and output taxes, and when to remit the net GST to the RMCD. They also need to be aware of the penalties for non-compliance.

It is also important to identify business operators' level of awareness, and the issues and problems that business operators are likely to encounter with the implementation of GST. These could be useful inputs for the RMCD to plan necessary programmes, trainings and dissemination of appropriate GST information to enhance awareness, knowledge, support and acceptance of the GST regime.

\footnotetext{
14 The types of goods and services exempted from GST are gazetted under Goods \& Services Tax (Exempt Supply) Order 2014.
} 


\section{Objective of Study}

The objective of this study is to identify the factors affecting business operators' awareness on the implementation of GST and the perceived issues and problems they may likely encounter with the implementation of GST.

This paper consists of six parts. Following the introduction in Part 1, Part 2 provides brief discussion on prior studies on awareness, issues and problems with regards to the implementation of GST. The conceptual framework and hypothesis development are presented in Part 3. Part 4 discusses on the research methodology for this study which includes research method, research sampling, research instrument and data collection. Part 5 presents the findings and analysis of this study. Lastly, Part 6 elaborates on the conclusion of findings, contributions and limitation of study.

\section{LITERATURE REVIEW}

Awareness of GST among business operators is important to ensure that they collect the appropriate taxes from their customers and comply with all other requirement of GST. Prior studies (Choong \& Lai, 2006; Saira, Zariyawati \& May, 2010; Samsuddin, et. al., 2014) showed that awareness of GST implementation is related to education background, levels of education, types of employment and initiatives of tax authority in conducting GST seminars, talks or dialogues.

Palil, Zaini and Mamat (2013) examined consumers' readiness, perception and acceptance of GST in Malaysia and found that the majority (73.2\%) of the respondents were aware about the implementation of GST while $53.6 \%$ believed that GST would have significant impact of their livelihood. Saira Saira, K., Zariyawati, M.A., \& May et al. (2010) found that 95\% of the respondents were aware that GST is a major source of government revenue, although around $50 \%$ did not understand the operations of the GST system. This study also revealed that nonaccounting students did not understand what GST is all about. This implies that tax knowledge and education could probably have bearings on the awareness of the implementation of GST.

Another study found that $77.2 \%$ of the respondents were aware about the implementation of GST but most of them were not ready for GST implementation (Abdullah, Idrus \& Mehat, 2013). $52.5 \%$ of the respondents also perceived GST to be not suitable in Malaysia and $47.5 \%$ were aware that GST might affect their spending behaviour. In this study, respondents' level of education showed positive relationship with their level of understanding towards GST. Besides, taxpayers' ethnicity is also found to be associated with their level of awareness towards tax (Jaidi, Noordin \& Kassim, 2013). A study investigated the level of awareness among educators found that $93.8 \%$ of the respondents were aware of the GST system, although $60.2 \%$ indicated that the level of information provided by the relevant authorities was moderately useful (Samsuddin, et. al., 2014). 
Public education on the GST implementation appears to be the right direction that tax authority needs to conduct widespread GST education campaigns, form call centres to disseminate information on GST implementation to the public and business operators nationwide (Choong \& Lai, 2006; Chan, 2009). These programmes include seminars, field visits, hotlines, dialogue sessions, brochures, media campaign and direct mailers. In order to reduce the burden of small businesses, tax education such as free seminars on tax compliance, use of technology, electronic lodgement and others should be organised by the relevant authority (Pope, 2001).

In Singapore, a broad taxpayer education programme was launched to educate the public on GST (Jenkins \& Khadka, 1998). The Inland Revenue Authority of Singapore (IRAS) conducted dialogue session to get input from businesses on their business process and designed the GST system that would not be unreasonably complex. The trade associations also collaborated with the IRAS to educate business owners by providing logistic support while the IRAS provided technical support. The education programmes explained the rational of GST implementation and enhanced public awareness on the GST system. Most of the small and medium enterprises (SMEs) owners' awareness of tax laws and procedures are the results from training, seminars and visitations by revenue officers (Lubua, 2014).

A proper channel of communication to share and to deliver information and knowledge and to cultivate positive attitude towards GST system is essential for enhancing the level of acceptance on the implementation of GST (Zhou, Tam \& Heng-Contaxis, 2013). For instance, in the United Kingdom, Chinese taxpayers did not apply for tax credit due to lack of awareness and access to information on tax credits (HM Revenue \& Customs, 2010). Therefore, public awareness and good education campaign could ensure the acceptance and smooth introduction of a new tax system (Yew, 2009) and also to raise sufficient revenue to finance governments' expenditures (Abdullah, 2012).

The implementation of GST will require business operators to keep appropriate and adequate accounting records (Alebel, 2011). Proper documentation and accounting records are essential in the event of tax audit and investigation. The lack of appropriate records could lead to SMEs' failure to comply with tax legislations (Abdul-Jabbar, 1996). Thus, in order to comply with the GST legislations, SMEs might need to hire new personnel to handle all documentation related to GST.

SMEs operators also encountered difficulties in complying with various and complicated tax legislations and regulations due to their limited resources and inadequate expertise (Pope \& Abdul-Jabbar, 2008). Thus, the implementation of GST would be another added tax compliance burden. SMEs faced a relatively higher compliance cost upon GST implementation, which is regressive for smaller organizations (Pope, 2001; Palil et al, 2013; Grinberg, 2006). GST compliance cost among businesses would be high, particularly for businesses that are involved with various taxable and exempted supplies (Palil \& Ibrahim, 2012).

Compliance costs can be divided into two categories; namely GST start-up (or implementation) cost and annual recurring (or on-going) cost (Brown \& Marsden, 2002). GST 
implementation cost comprised of additional expenditure on computer upgrading, staff cost to adjust the pricing of products, training and IT consultation cost, cost for extra bookkeeping requirements and also time costs spent by business owners on GST related activities, such as spending more time on paperwork and on collecting taxes. Study on GST compliance costs in the service sector in Queensland showed that the mean start-up cost is around $\$ 5,610^{15}$ per organization while the mean for recurrent cost is approximately $\$ 5,600$ (Breen, Bergin-Seers \& Sims, 2002).

On-going GST cost is a substantial burden in relation to GST compliance. Delayed payments by firms' debtors created cash flows problems when the businesses need to pay their GST commitments. A study on 868 small businesses by Rametse (2010) found that the preparation for GST implementation was a heavy management and financial burden for each business, with an average of $\$ 7,888$ start-up cost being incurred on equipment, professional fees and stationery. In addition, in terms of time costs, 131 hours were spent, costing to $\$ 2,882$ to seek professional accounting and information technology advice, and 58 hours (about \$1,276 in monetary term) in preparing GST.

In Australia, total GST implementation costs were almost double ( $\$ 4.5$ billion) as compare to the first-year GST operating costs ( $\$ 2.5$ billion), and that high GST implementation costs have negative consequences on economy in various ways (Tran-Nam, 2000). Therefore, in order to reduce compliance costs a simplified method of computing such tax should be introduced (Chan, 2009).

In Malaysia, before the implementation of GST, the expected GST compliance cost for SMEs was RM28,456 (Palil, et. al., 2013). The annual compliance cost consist of internal cost of RM16,772 (58.87\%), external cost of RM7,388 (26.01\%) and additional cost of RM4,296 (15.42\%). Expected cost could increase due to external sourcing of services for GST tax computation and tax planning. On an average, an additional cost of RM6,336 was expected to be incurred on external sourcing of services, and that most of the companies expected an increase in internal cost for tax computation and tax planning after the implementation of GST.

Relative to sales or assets value, SMEs faced higher compliance costs as compared to large businesses (Weichenrieder, 2007; Slemrod \& Venkatesh, 2002). In general, compliance cost vary significantly, depending on business size (Breen, Bergin-Seers \& Sims, 2002). In Nigerian, an average of $\$ 67,995$ was spent on tax compliance cost for SMEs who were engaged in VAT transactions (Eragbhe \& Modugu, 2014). It is also noted that on average, VAT compliance cost burden was higher than compliance cost for other types of taxes, such as income tax, withholding tax, and customs and excise duties.

\section{CONCEPTUAL FRAMEWORK AND HYPOTHESIS DEVELOPMENT}

This study has identified four factors namely, business experience, ethnicity of business operators, business size and business initiatives that might have association with business

15 The \$ monetary value refers to is the Australian dollar.

[Type here] 
operators' awareness of, and the perceived issues and problems ${ }^{16}$ on the implementation of GST they might encounter (see Figure 1).

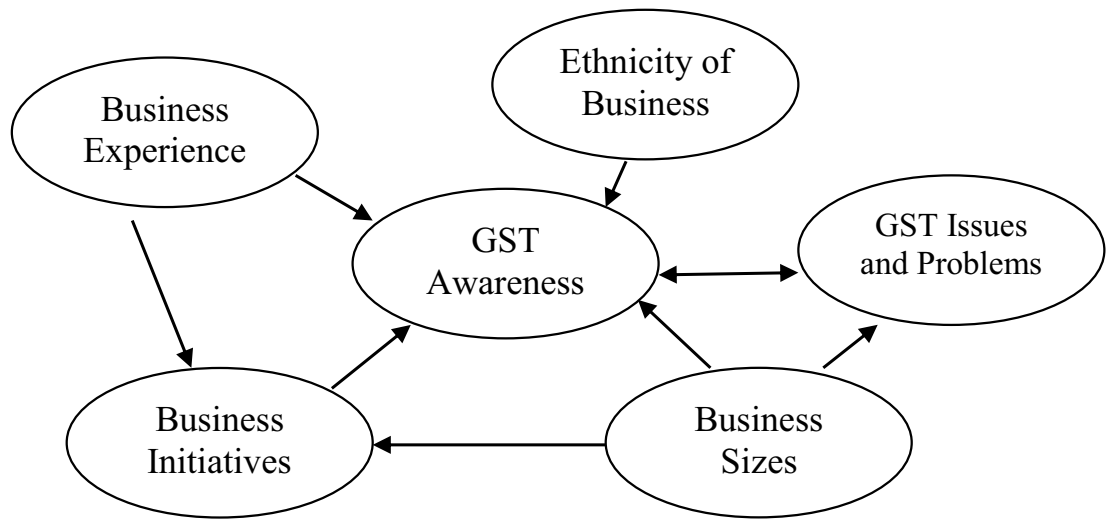

Figure 1: Conceptual Framework

Business experience refers to prior experience in dealing with SST. Although the mechanism and approaches between SST and GST are different, knowledge and experience with SST would be an added advantage to business operators. Previous experience with SST made an important difference on careful preparation of VAT returns (Casanegra de Jantscher, 1987), as business operators with experience in dealing SST would likely to be more aware of the mechanism, regulations and requirements of GST. They could be more knowledgeable in dealing with issue and problems related GST. In addition, business operators with longer period of operations would probably have better understanding of the business environment.

The implementation of GST requires businesses to keep appropriate accounting records (Alebel, 2011). However, SMEs have experienced difficulties in maintaining proper records for business and taxation purposes (Hanefah \& Al-Mureshi, 1991). The lack of appropriate record keeping had led to SMEs' failure to comply with tax legislations (Abdul-Jabbar, 1996) and also being audited by tax authorities (Yong, 2011). Hence, business experience in tax audit might influence taxpayers' documentation practices and their tax compliance costs. Therefore, the following hypotheses are formulated:

$\mathrm{H}_{1}$ : There is a relationship between business experience and GST awareness.

$\mathrm{H}_{2}$ : There is a relationship between business experience and perceived issues and problems (in relation to record keeping and compliance cost)

Ethnicities are groups of community with a set of shared cultural values, beliefs and norms to solve their basic social problems (Basu \& Altinay, 2002). In New Zealand, Maori and Pacific SMEs were found to have difficulties in tax payments as compared to Europeans and Asians (Yong, 2011). In Nigeria, different ethnic groups faced different social, technical and logistic problems when dealing with the VAT system (Oladipupo \& Izedonmi, 2013).

\footnotetext{
${ }^{16}$ In this study, "GST issues and problems" refer to the perceived issues and problems (as per Table 6) that business operators are likely to face on the implementation of GST.
}

[Type here] 
In the context of this study, ethnicity of business operators consists of three major groups: Malay, Chinese and Indian business operators who are members of Chambers of Commerce. It is noted that when the Government decided to implement GST, the Chinese Chambers of Commerce had organised various seminars, dialogues and relevant GST courses to create awareness among its members. Hence, members of the Chinese Chambers of Commerce might be more aware on the implementation of GST. It is expected that the ethnicity of business operators has association with their awareness of GST.

In terms of documentation and compliance costs, it is possible that different ethnic communities may have different documentation practices such as filing and records keeping and to a certain extent ethnicity of business operators may face different GST compliance cost. Thus, it is hypothesised that:

$\mathrm{H}_{3}$ : Ethnicity of business operators is associated with their awareness of GST.

$\mathrm{H}_{4}$ : There is an association between ethnicity of business operators and GST issues and problems (related to records and compliance cost).

Business operators' awareness of, and perceived issues and problems that they might face on the implementation of GST might also be influenced by business size. This study classified business size into two categories, namely businesses with threshold of less than RM500,000 and with threshold of more than RM500,000. Business operators achieving the threshold of more than RM500,000 are liable to be registered as GST taxable persons. These business operators are expected to source for relevant information on GST, and therefore be more aware of GST implementation. In contrast, business operators who have no legal obligation to register may not be so interested, thus would likely be less aware of GST implementation and of issues and problems related to GST implementation.

The implementation of GST could give rise to additional compliance burdens and compliance costs in relation to record keeping and could create major problems for businesses (Palil et al., 2013). SMEs faced a relatively higher cost of GST implementation (Pope, 2001) would incur relatively more costs on resources to manage their tax affairs (Palil et al, 2013). Generally, compliance cost vary significantly, depending on business size (Breen, Bergin-Seers, \& Sims, 2002). As such, the hypotheses formulated are:

$\mathrm{H}_{5}$ : There is a relationship between business size and awareness of GST.

$\mathrm{H}_{6}$ : There is a relationship between business size and GST issues and problems (related to records and compliance cost)

Business initiatives refer to initiatives to seek for more information on GST. These include attending seminars, talks, trainings and purchase of publications related to GST implementation. Study found a substantial difference in knowledge between taxpayers who had attended and those who did not attend any tax seminars, talks or trainings (Palil, 2010). If business operators take more of such initiatives, they are expected to be more aware and have better understanding of GST, hence, able to identify any possible problems in relation to GST that may arise. 
It is noted that the main driving factor of tax compliance costs is due to insufficient knowledge of business owners (European Commission, 2007). SME operators lacking in tax knowledge faced more challenges with income tax and VAT (Maseko, 2014). Insufficient technical knowledge on tax matters likely to be even more critical among the self-employed who have to deal with GST affairs (Saad, 2014).

Thus, it is envisaged that business operators who engaged in business initiatives to enhance their tax knowledge are more aware of GST and able to deal with any major issues and problems in relation to GST compliance, such as costs of compliance and documentation. Thus, the hypotheses are formulated as follows:

$\mathrm{H}_{7}$ : There is a relationship between business initiatives and awareness of GST.

$\mathrm{H}_{8}$ : There is a relationship between business initiatives and GST issues and problems (related to records and compliance cost)

\section{RESEARCH METHODOLOGY}

To address the objective of this study, a quantitative research using survey is conducted. Quantitative research is generally used to measure respondents' behaviour, knowledge, attitudes or opinion, and also used to answer questions such as how long, how much, how often, who, what and when (Cooper \& Schindler, 2014). Survey is chosen to gather primary data in order to describe a population too huge to observe directly.

\section{Research Sampling}

Hair, Money, Samouel and Page (2007) defined population as a group of knowledgeable people. Target population is defined in terms of elements, geographical boundaries and time (Sekaran \& Bougie, 2009) which allows researchers to make some forms of interpretations (Cooper \& Schindler, 2014). The population of this study consists of registered members of three Chambers of Commerce in Melaka, namely the Malay Chambers of Commerce of Melaka, Melaka Chinese Chamber of Commerce and Industry and Melaka Indian Chamber of Commerce and Industry.

Stratified random sampling was used to select respondents from the three Chambers of Commerce in Melaka. The advantage of stratified random sampling is the possibility to compare information among groups (Sekaran \& Bougie, 2009). It is because stratified random sampling divides the population into homogenous subgroups that have differences and nonoverlapping which enables researchers to make comparison between different ethnicity of the business operators in relation to awareness and perceive issues and problem of GST implementation. 
Table 1: Registered Members of Chambers of Commerce, Sample Size and Response Rate among Respondents

\begin{tabular}{|c|c|c|c|c|}
\hline \multirow{2}{*}{ Chambers of Commerce } & \multirow{2}{*}{ Number of Registered Members * } & Sample Size & \multicolumn{2}{|c|}{ Response Rate ** } \\
\cline { 3 - 5 } & & $\mathbf{5 0 \% )}$ & No & $\mathbf{\%}$ \\
\hline Malay & 144 & 72 & 64 & 88.9 \\
\hline Chinese & 399 & 200 & 90 & 45.0 \\
\hline Indian & 60 & 30 & 30 & 100 \\
\hline Total & 478 & 302 & 184 & \\
\hline
\end{tabular}

* Source: Registers of the respective Chambers of Commerce in Melaka.

**The response rate is based on the number of questionnaires distributed to and returned by the members of the respective particular Chambers of Commerce. Collectively, for all the three Chambers of Commerce, the response rate is $60.93 \%$.

$50 \%$ of members from each Chamber of Commerce in Melaka were selected, which formed a total sample size of 302 for this study (see Table 1).

\section{Research Instrument}

The questionnaire consists of four sections. Section 1 elicits data on the nature of business, ethnicity of business operators, the business annual gross turnover and GST registration status. This section also elicits data on whether the business was licensed under SST, and whether business operators had attended any seminars or training related to GST.

Section 2 elicits responses relating to the business operators' level of awareness on the implementation of GST in Malaysia. Section 3 comprised of 13 statements, aimed at identifying perceived issues and problems likely to be faced by the business operators when complying with the GST legislations. Respondents were requested to response to the statements based on a five-point Likert-scale (of which 1=strongly disagree, 2=disagree, $3=$ neither agree not disagree, $4=$ agree and $5=$ strongly agree).

Section 4 of the questionnaire provided an open-ended question allowing respondents to provide further comments and general opinion on the implementation of GST in Malaysia.

In order to check the validity and clarity of statements listed in the questionnaire, a pilot test was conducted where 10 sets of questionnaire were distributed to selected academics and business operators in Melaka. Subsequently, amendments were made to ensure clarity of wordings used in the questionnaires.

\section{Data Collection}

Questionnaires were distributed to the 302 selected samples (See Table 1). Only 60.93\% of usable sets of questionnaire were returned. Sandford (1995) stated that response rate of survey study would probably be around $30 \%$. Therefore, the response rate for this study was reasonably high and adequate for analysis. 


\section{FINDINGS AND ANALYSIS}

\section{Profile of the respondents}

With regard to ethnicity of business operators, $34.8 \%$ are Malays, $48.9 \%$ are Chinese and $16.3 \%$ are Indians. In terms of industry sectors, $37.5 \%$ are from the service sector, followed by trading $(27.7 \%)$, manufacturing $(10.9 \%)$ and transport and storage $(5.4 \%)$, while the "other" category (such as hotel, hire purchase, food and beverage, bookstore, insurance and motorcycle businesses) making up of the remaining $18.5 \%$.

Table 2 below shows the cross tabulation results of business with annual gross turnover and registration for GST. Compulsory registration is only applicable to those with annual gross turnover exceeded RM500,000. Of the total respondents, $37 \%$ had registered (i.e. "compulsory registration"), while $14 \%$ who ought to be registered have yet to do so. Of the total respondents, $6 \%$ opted for voluntary registration, citing the rationale as "to comply with the law, ${ }^{17}$ increase profitability of their business, to be eligible for input tax credit and to enjoy any benefit as may be provided by tax authority". On the other hand, the reasons given by those who did not opt for voluntary registration are "having to incur additional costs of doing business, did not have staff to handle GST, increased billing charges on customers, GST is very complicated, waste of money and time to learn about GST and GST does not bring benefits to their business, they do not agree with GST implementation, running a small business with not enough time to manage GST matters".

Table 2: Respondent's Business Turnover and Registration for GST

\begin{tabular}{|l|c|c|c|c|c|c|}
\hline \multirow{2}{*}{ Annual Gross Turnover } & \multicolumn{4}{|c|}{ GST Registration } & \multirow{3}{*}{ Total Number } & \multirow{2}{*}{$\%$} \\
\cline { 2 - 5 } & \multicolumn{3}{|c|}{ Yes } & \multicolumn{2}{|c|}{ No } & \\
\cline { 2 - 5 } & No. & $\%$ & No. & $\%$ & & 49 \\
\hline Less than RM500,000 & 11 & 6 & 80 & 43 & 91 & 51 \\
\hline More than RM500,000 & 68 & 37 & 25 & 14 & 93 & 100 \\
\hline Total & 79 & 43 & 105 & 57 & 184 & 100 \\
\hline
\end{tabular}

Of the total respondents, only $36.4 \%$ were licensed SST taxable person. Only slightly more than half $(52.5 \%)$ of the respondents have attended seminars, dialogues, training or conference related to GST. The reasons cited by the remaining $47.5 \%$ for not attending any courses on GST are that "they did not get any invitation, headquarters are in-charge for GST training, GST has yet to be implemented ${ }^{18}$ and not willing to incur extra cost to attend GST courses".

\section{Reliability and Validity Test}

Reliability and validity tests were conducted on the statements listed in the questionnaire. Reliability is a test on how consistent a measuring instrument measures whatever concept it is measuring (Sekaran \& Bougie 2009; Hair et al., 2007). Cronbach's alpha reliability coefficient indicates how well the items in a set are positively associated to one another.

\footnotetext{
${ }^{17}$ The word "voluntary" implies that voluntary registration is in fact not mandatory under the GST legislation.

${ }^{18}$ The questionnaires were administered about 6 months prior to the coming effect of GST on 1 April 2015.
} 
Internal consistency is considered reliable when Cronbach's alpha is closer to 1 (Sekaran \& Bougie, 2009).

As presented in Table 3, the Cronbach's Alpha values of more than 0.8 for the variables (awareness and issues and problems) suggest that the instrument used is valid and of a high degree of reliability.

Table 3: Reliability Test

\begin{tabular}{|c|c|c|c|}
\hline Variables & Cronbach's Alpha & $\begin{array}{c}\text { Cronbach's Alpha Based on } \\
\text { Standardized Items }\end{array}$ & No of Items \\
\hline Awareness & 0.925 & 0.927 & 28 \\
\hline Issues and Problems & 0.902 & 0.909 & 13 \\
\hline
\end{tabular}

Validity is defined as evidence that the instrument, technique or process used to measure a concept does indeed measure the intended concept (Sekaran \& Bougie, 2009). Validity is also related to the term accuracy (Hair et al., 2007). If the Kaiser-Meyer-Olkin (KMO) value is greater than 0.5, the variables used are acceptable and valid (Kaiser, 1974). The value of KMO (0.787) presented in Table 4 shows that the variables for awareness, issues and problems used in the instrument are acceptable.

Table 4: Validity Test

\begin{tabular}{|c|c|c|}
\hline Kaiser-Meyer-Olkin (KMO) & ng Adequacy & .787 \\
\hline & Approx. Chi-Square & 8620.745 \\
\hline Bartlett's Test of Sphericity & df & 1711 \\
\hline & Sig. & .000 \\
\hline
\end{tabular}




\section{GST Awareness among Business Operators}

The majority $(>70 \%)$ of the respondents are aware of the GST mechanism. The detail findings of awareness of GST mechanism are presented in Table 5.

Table 5: GST Awareness among Business Operators

\begin{tabular}{|c|c|c|c|c|}
\hline \multirow[t]{2}{*}{ Awareness of GST Mechanism } & \multicolumn{2}{|c|}{ Yes } & \multicolumn{2}{|l|}{ No } \\
\hline & Number & $\%$ & Number & $\%$ \\
\hline $\begin{array}{l}\text { GST will be charged at } 6 \% \text { when implemented on } 1 \text { st } \\
\text { April } 2015 \text {. }\end{array}$ & 177 & 96.2 & 7 & 3.8 \\
\hline GST is a multi-stage tax. & 134 & 72.8 & 50 & 27.7 \\
\hline $\begin{array}{l}\text { The } 3 \text { categories of GST supply are: } \\
\text { i. } \quad \text { standard rated supply }\end{array}$ & 167 & 90.8 & 17 & 9.2 \\
\hline ii. zero-rated supply & 148 & 80.4 & 36 & 19.6 \\
\hline iii. exempt supply & 143 & 77.7 & 41 & 22.3 \\
\hline $\begin{array}{l}\text { Under the GST regime, any business with an annual threshold of more than } \\
\text { RM500,000 is required to register with the Royal Malaysia Customs } \\
\text { Department (RMCD). }\end{array}$ & 150 & 81.5 & 34 & 18.5 \\
\hline $\begin{array}{l}\text { Any business with an annual threshold of RM500,000 and below may apply } \\
\text { for voluntary registration with the RMCD. }\end{array}$ & 133 & 72.3 & 51 & 27.7 \\
\hline $\begin{array}{l}\text { Generally any business that is registered for GST is eligible to claim input } \\
\text { tax. }\end{array}$ & 122 & 66.3 & 62 & 33.7 \\
\hline $\begin{array}{l}\text { The following goods } \ldots \text { are not subject to GST: } \\
\text { i. sugar }\end{array}$ & 165 & 89.7 & 19 & 10.3 \\
\hline ii. flour & 162 & 88 & 22 & 12 \\
\hline $\begin{array}{l}\text { fish } \\
\text { frozen food }\end{array}$ & 144 & 78.3 & 40 & 21.7 \\
\hline $\begin{array}{l}\text { 1V. frozen food } \\
\text { The following services } \ldots \text { are exempted from GST: }\end{array}$ & 112 & 60.9 & 72 & 39.1 \\
\hline i. public transportation & 143 & 77.7 & 41 & 22.2 \\
\hline $\begin{aligned} \text { ii. } & \text { banking } \\
\text { iii. } & \text { education }\end{aligned}$ & $\begin{array}{l}144 \\
156\end{array}$ & $\begin{array}{l}78.3 \\
84.8\end{array}$ & $\begin{array}{l}40 \\
28\end{array}$ & $\begin{array}{l}21.7 \\
15.2\end{array}$ \\
\hline $\begin{array}{l}\text { When the output tax is less than input tax, business operator is entitled to } \\
\text { refund from Royal Malaysia Customs Department. }\end{array}$ & 134 & 72.8 & 50 & 27.2 \\
\hline $\begin{array}{l}\text { Business and accounting records related to GST must be kept for a period of } \\
7 \text { years. }\end{array}$ & 143 & 77.7 & 41 & 22.2 \\
\hline $\begin{array}{l}\text { The Royal Malaysia Customs Department is an entity responsible to collect } \\
\text { GST from the registrants of GST in Malaysia. }\end{array}$ & 161 & 87.5 & 23 & 12.5 \\
\hline $\begin{array}{l}\text { Businesses are required to: } \\
\text { i. } \\
\text { submit GST returns not later than the last day of the following month } \\
\text { after the taxable period }\end{array}$ & 128 & 69.6 & 56 & 30.4 \\
\hline $\begin{array}{l}\text { ii. remit GST not later than the last day of the following month after the } \\
\text { taxable period of GST return }\end{array}$ & 130 & 70.7 & 54 & 29.3 \\
\hline $\begin{array}{l}\text { Penalty may be imposed on any business registered under GST for following } \\
\text { offences : } \\
\text { i. deficiency on the net tax payable }\end{array}$ & 137 & 74.5 & 47 & 25.5 \\
\hline $\begin{array}{l}\text { 1. } \text { deficiency on the net tax payable } \\
\text { ii. }\end{array}$ & 134 & 72.8 & 50 & 27.2 \\
\hline GST return is submitted without payment & 132 & 71.7 & 52 & 28.3 \\
\hline iv. GST return is submitted with insufficient payment & 129 & 70.1 & 55 & 29.9 \\
\hline $\begin{array}{l}\text { For refund purposes, payment will be made within } \\
\text { i. } \quad 14 \text { working days if it was submitted online }\end{array}$ & 148 & 80.4 & 36 & 19.6 \\
\hline ii. 28 working days for manual submission. & 133 & 72.3 & 51 & 27.7 \\
\hline $\begin{array}{l}\text { Businesses registered under GST are required to issue tax invoice within } 21 \\
\text { days when the supply is deemed to have taken place. }\end{array}$ & 136 & 73.9 & 48 & 26.1 \\
\hline
\end{tabular}

[Type here] 


\section{Perceived Issues and Problems Faced by Business Operators}

More than two-thirds of the respondents agreed with the perceived issues and problems that they might face upon the implementation of GST. The details of the findings on such perceived issues and problems are presented in Table 6.

Table 6: Issues and Problems faced by Business Operators on GST Implementation

\begin{tabular}{|c|c|c|c|c|c|c|c|}
\hline Statements & $\begin{array}{l}\text { SD } \\
\text { No. } \\
(\%)\end{array}$ & $\begin{array}{c}\text { D } \\
\text { No. }(\%)\end{array}$ & $\begin{array}{c}\mathrm{N} \\
\text { No. }(\%)\end{array}$ & $\begin{array}{c}\text { A } \\
\text { No. }(\%)\end{array}$ & $\begin{array}{c}\text { SA } \\
\text { No. }(\%)\end{array}$ & Mean & STD \\
\hline $\begin{array}{l}\text { With the implementation of GST: } \\
\text { •Your business will face problems to keep } \\
\text { all relevant business records to comply with } \\
\text { GST legislations. }\end{array}$ & $5(2.7)$ & $26(14.2)$ & $24(13)$ & $105(57.1)$ & $24(13)$ & 3.64 & 0.97 \\
\hline $\begin{array}{l}\text {-All documents to be kept for } 7 \text { years will } \\
\text { lead to storage problem for your business. }\end{array}$ & $7(3.8)$ & $22(12)$ & $34(18.5)$ & $106(57.5)$ & $15(8.2)$ & 3.54 & 0.94 \\
\hline $\begin{array}{l}\text {-The compliance costs to implement GST } \\
\text { in your business will be higher. }\end{array}$ & $10(5.4)$ & $18(9.9)$ & $30(16.3)$ & $95(51.6)$ & $31(16.8)$ & 3.65 & 1.05 \\
\hline $\begin{array}{l}\text {-Your business will need to hire new } \\
\text { personnel to manage GST matters. }\end{array}$ & $10(5.4)$ & $29(15.8)$ & $41(22.3)$ & $79(42.9)$ & $25(13.6)$ & 3.43 & 1.08 \\
\hline $\begin{array}{l}- \text { Your existing staff will have to attend } \\
\text { training courses in order to learn to manage } \\
\text { GST matters. }\end{array}$ & $8(4.3)$ & $23(12.5)$ & $20(10.9)$ & $114(62)$ & $19(10.3)$ & 3.61 & 0.98 \\
\hline $\begin{array}{l}\text {-Your business will face problems in } \\
\text { setting the prices of goods and services } \\
\text { provided to customers. }\end{array}$ & $10(5.4)$ & $21(11.5)$ & $33(17.9)$ & $96(52.2)$ & $24(13)$ & 3.56 & 1.03 \\
\hline $\begin{array}{l}\text {-Your business still does not know how } \\
\text { GST will affect your business. }\end{array}$ & $23(12.5)$ & $41(22.3)$ & $26(14.1)$ & $75(40.8)$ & $19(10.3)$ & 3.14 & 1.24 \\
\hline $\begin{array}{l}\text { Your business will have problems to } \\
\text { comply with GST such as: } \\
\text { - keep proper accounting records }\end{array}$ & 603 & & & & & & 089 \\
\hline - filing GST returns & $6(3.3)$ & $18(9.8)$ & $31(16.8)$ & $112(60.9)$ & $17(9.2)$ & $\begin{array}{l}5.52 \\
3.63\end{array}$ & $\begin{array}{l}0.09 \\
0.90\end{array}$ \\
\hline - remit GST & $6(3.3)$ & $21(11.4)$ & $40(21.7)$ & $110(59.8)$ & $7(3.8)$ & 3.49 & 0.87 \\
\hline - claim input tax credit & $4(2.2)$ & $16(8.7)$ & $44(23.9)$ & $108(58.7)$ & $12(6.5)$ & 3.59 & 0.83 \\
\hline $\begin{array}{l}\text { The information and explanation on GST } \\
\text { provided by RMCD is insufficient to deal } \\
\text { with GST implementation. }\end{array}$ & $10(5.4)$ & $26(14.2)$ & $50(27.2)$ & $74(40.2)$ & $24(13)$ & 3.41 & 1.06 \\
\hline $\begin{array}{l}\text { GST will increase compliance cost in } \\
\text { running your business. }\end{array}$ & $8(4.3)$ & $22(12)$ & $25(13.6)$ & $109(59.2)$ & $20(10.9)$ & 3.60 & 0.98 \\
\hline
\end{tabular}

Note: $S D=$ Strongly Disagree; $D=$ Disagree $;=$ Neither Agree nor Disagree; $A=$ Agree $;$ SA $=$ Strongly Agree, $S T D=$ Standard Deviation

Kruskal-Wallis Test was used to test whether there is any significant difference among three different groups of ethnicity namely Malay, Chinese and Indian in terms of awareness, issues and problems on the implementation of GST. At 0.05 significance levels, there is no statistically significant difference among the three groups of ethnicity with regards to awareness $\left(\chi^{2}=1.306, p=0.520\right)$ and issues and problems $\left(\chi^{2}=4.437, p=0.109\right)$ on the implementation of GST.

\section{Correlation Analysis}

Correlation analysis is used to measure strength association between two or more variables. Correlation results presented in Table 7 shows that business experience (BE) in dealing with 
the SST has no significant relationship with level of awareness (AW, $r=.130)$ and perceived issues and problem (IP, $\mathrm{r}=.007$ ) likely to be faced by business operators on the implementation of GST. Therefore, $\mathrm{H}_{1}$ and $\mathrm{H}_{2}$ are rejected.

Ethnicity of business operators (EBO) shows no significant association with the level of awareness (AW, $\mathrm{r}=.016)$ and perceived issues and problems (IP, $\mathrm{r}=.102)$ likely to be faced by business operators on the implementation of GST. Thus, $\mathrm{H}_{3}$ and $\mathrm{H}_{4}$ are rejected. This result contradicts with the findings of Jaidi et al. (2013) which revealed that taxpayer's awareness levels were associated with their ethnicity. Similarly, this result also contradicts with the findings of Yong and Hulst (2014) who indicated that cultural value of ethnic groups are associated with their tax compliance practices and perceptions.

At 0.01 significance levels, business size (BS) shows significant relationship ( $r=.224)$ with the level of awareness (AW) on the implementation of GST, while at 0.05 significance level, business size (BS) shows significant relationship $(\mathrm{r}=.184)$ with perceived issues and problems (IP) faced by business operators on the implementation of GST. The results indicate that business operators who have an annual turnover of more than RM500,000 are more aware of the GST mechanism. This result implies that business operators who are liable to be registered would take initiatives to acquire knowledge and identify issues related to GST. Thus, it can be concluded that $\mathrm{H}_{5}$ and $\mathrm{H}_{6}$ are accepted.

Table 7: Spearman Correlations

\begin{tabular}{|l|l|c|c|c|c|c|c|}
\hline & & BE & EBO & BS & BI & AW & IP \\
\hline Business Experience & BE & 1 & -.071 & $.161^{*}$ & .102 & .130 & .007 \\
\hline Ethnicity of Business Operators & EBO & & 1 & -.073 & .084 & -.016 & .102 \\
\hline Business Size & BS & & & 1 & $.337^{* *}$ & $.224^{* *}$ & $.184^{*}$ \\
\hline Business Initiatives & BI & & & & 1 & $.283^{* *}$ & $.323^{* *}$ \\
\hline Awareness & AW & & & & & 1 & $.346^{* *}$ \\
\hline Issues \& Problems & IP & & & & & 1 \\
\hline
\end{tabular}

At 0.01 level of significance, business initiatives (BI) shows significant relationship with awareness (AW, $\mathrm{r}=.283$ ), issues and problems (IP, $\mathrm{r}=.323$ ) towards the implementation of GST among business operators. This shows that initiatives taken by business operators to attend courses related to GST do have influence on their level of awareness of GST and on perceived issues and problems that may arise when GST is implemented. Therefore, $\mathrm{H}_{7}$ and $\mathrm{H}_{8}$ are accepted. This result is consistent with the study of Saira, Zariyawati and May (2010) that lack of knowledge and information on GST could lead to low level of awareness regarding the implementation of GST.

It is noted that at the significance level of 0.01 , awareness (AW) of the implementation of GST and perceived issues and problems (IP) likely to be experienced are positively correlated $(\mathrm{r}=.346)$. 


\section{CONCLUSION, LIMITATION AND FUTURE RESEARCH}

More than $70 \%$ of the respondents are aware of the GST mechanism, which implies that businesses operators do have adequate knowledge on GST in order to face the challenges arising from the implementation of GST. This finding is consistent with that of previous research by Palil, et. al. (2013) but contradicts the findings by Saira, Zariyawati and May (2010).

Most of the business operators agreed with the perceived issues and problems in keeping relevant business records, storage of document, hiring of new personnel and training for existing staff in managing GST matters would lead to higher compliance costs, which is consistent with the finding by Alebel (2011). The respondents also agreed that they would face problems in re-setting prices of goods and services, filing GST returns, remitting GST due, as well as in claiming input tax refunds.

Business size and business initiatives are found to have positive relationship with awareness of GST, and perceived issues and problems they are likely to face. This study found that business operators with annual gross turnover of more than RM500,000 are more likely to have higher level of awareness pertaining to GST and are more aware of the perceived issues and problems that they may encounter.

\section{Contribution of Study}

This study provided useful evidence pertaining to business operators' level of awareness on, and concerns regarding the perceived issues and problems associated with the implementation of GST. Besides, the findings would be useful inputs for the relevant tax authorities, policy makers and other stakeholders to formulate plans and strategies to address the issues and problems that are likely to be encountered by business operators and to enhance the level of compliance.

\section{Limitation of Study}

It is acknowledged that the findings of this study cannot be generalised to the whole population of Malaysia business operators as the samples are restricted to the registered members of the three Chambers of Commerce in Melaka. Besides, this study only examined the association of four factors (business experience, ethnicity of business operators, business size and business initiatives), level of awareness on GST, and the perceived issues and problems likely to be encountered by business operators.

\section{Recommendation for Future Research}

For future research, the target respondents could be extended to those in other States in Malaysia. A comparative study among business operators in different States would be useful to examine whether there is any significant difference between business operators in the different States. Future study could also include other possible factors that may be associated 
with the level of awareness as well as issues and problems likely to be encountered in relation to compliance with GST legislations.

\section{REFERENCES:}

Abdul-Jabbar, H. (1996). The implementation of scheduler monthly tax deduction: The case of small and medium industries in Kedah Darul Aman. Master Thesis, Universiti Utara Malaysia.

Abdullah, H., Idrus, A.A.M., \& Mehat, N. (2013). Kefahaman dan kesediaan pengguna terhadap pelaksanaan Cukai Barang dan Perkhidmatan (GST): Satu tinjauan awal. Prosiding Perkem, 2(8), 688-702.

Abdullah, K. (2012). Revenue mobilization measures and current tax issues. IMF-Japan High Level Tax Conference for Asian and Pacific Countries, 1-14.

Alebel, A.M.S. (2011). Goods and Services Tax: problems and effects of implementation. Business E-Bulletin, 1(1), 55-64.

Basu, A., \& Altinay, E. (2002). The interaction between culture and entrepreneurship in london's immigrant businesses. International Small Business Journal, 20(4), 371-393.

Breen, J., Bergin-Seers, S., \& Sims, R. (2002). The impact of the introduction of the GST on small business in Australia. Asian Review of Accounting, 10(1), 89-104.

Brown, K., \& Marsden, S. (2002). The impact of the gst on the community services sector in Queensland. In The Fifth International Conference on Tax Administration, 1-15.

Casanegra de Jantscher, Milka. 1987. Problems in administering a value-added tax in developing countries: an overview. Development Research Department discussion paper no. DRD 246. Washington, DC: World Bank

Chan, T. (2009). Goods and Services Tax in Malaysia. Accountants Today, 33.

Choong, K.F., \& Lai, M.L. (2006). Towards Goods and Services Tax in Malaysia: A Preliminary Study. Global Business \& Economics Anthology, 1, 75-86.

Cooper, D.R., \& Schindler, P.S. (2014). Business Research Methods (12th Edition). Boston: Mc-Graw-Hill.

Eragbhe, E., \& Modugu, K.P. (2014). Tax compliance costs of small and medium scale enterprises in Nigeria. International Journal of Accounting and Taxation, 2(1), 63-87.

European Commission. (2007). Simplified tax compliance procedures for SMEs: Final Report of the Expert Group. European Commission: Enterprise and Industry DirectorateGeneral.

Government of Malaysia. (2014). Law of Malaysia, Goods and Services Tax Act 2014. Percetakan Nasional Malaysia Berhad.

Government of Malaysia. (2014). Federal Government Gazette, Goods and Services Tax Regulations 2014. Attorney General Chamber.

Grinberg, I. (2006). Implementing a progressive consumption tax: Advantages of adopting the VAT Credit-Method System. National Tax Journal, LIX(4), 929-954.

Hair, J.F.J., Money, A.H., Samouel, P. \& Page, M. (2007) Research Methods for Business. United Kingdom: John Wiley \& Sons, Inc.

Hanefah, M., \& Al-Mureshi, A.L. (1991). Accounting in small and medium enterprises. Akauntan Nasional. 
HM Revenue \& Customs (2010), Engagement with tax credits among Chinese and Indian people. A study conducted for HM Revenue and Customs. Her Majesty's Research Report 117.

Jaidi, J., Noordin, R., \& Kassim, A.W.M. (2013). Individual taxpayers' perception towards self-assessment system: A case of Sabah. Journal of the Asian Academy of Applied Business, 2(1), 56-65.

Jenkins, G.P., \& Khadka, R. (1998). Value Added Tax policy and implementation in Singapore. International Bureau of Fiscal Documentation, 9(2), 35-47.

Lubua, E.W. (2014). Influencing tax compliance in SMEs through the use of ICTs. International Journal of Learning, Teaching and Education Research, 2(1), 80-90.

Maseko, N. (2014). The impact of personal tax knowledge and compliance costs on tax compliance behaviour of SMEs in Zimbabwe. Elite Research Journal of Accounting and Business Management, 2(3), 26-37.

Oladipupo, A.O., \& Izedonmi, F.P. (2013). Public perceptions and attitude towards Value Added Tax (VAT) in Nigeria. Scientific Research, 5, 126-135.

Palil, M.R. (2010). Tax knowledge and tax compliance determinants in self assessment system in Malaysia. Degree of Doctor of Philosophy Thesis, University of Birmingham.

Palil, M.R., \& Ibrahim, M.A. (2012). The impacts of Goods And Services Tax (GST) on middle income earners in Malaysia. World Review of Business Research, 1(3), 192-206.

Palil, M.R., Ramli, R., Mustapha, A.F., Syuhada, N., \& Hassan, A. (2013). Elements of compliance costs: Lesson from Malaysian companies towards Goods and Services Tax (GST). Asian Social Science, 9(11), 135-147.

Palil, M.R., Zain, N.H.M., \& Mamat, N.H. (2013). Consumer Readiness, Perceptions and Acceptance of Goods and Services Tax (GST): Middle and Lower Income Earners Perspective. Proceeding-Kuala Lumpur International Business, Economics and Law Conference, 1, 353-360.

Pope, J. (2001). Estimating and alleviating the Goods and Services Tax compliance cost burden upon small business. Revenue Law Journal, 11(1), 1-18.

Pope, J., \& Abdul-Jabbar, H. (2008). Small and medium-sized enterprises and tax compliance burden in Malaysia: Issues and challenges for tax administration. Small Enterprise Research, 16(1), 1-14.

Rametse, N. (2010). An International perspective on small business implementation costs of a new tax and managerial benefits received. Transforming black townships into economic powerhouses. Proceedings of the 2010 Soweto International Conference on Entrepreneurship \& Development, South Africa, 27-28 January, 1-24.

Saad, N. (2014). Tax knowledge, tax complexity and tax compliance:taxpayers' view. Procedia - Social and Behavioural Sciences, 109, 1069-1075.

Saira, K., Zariyawati, M.A., \& May, L.Y. (2010). An exploratory study of Goods and Services Tax awareness in Malaysia, 265-276. Retrieved from repo.uum.edu.my/3178/1/S14.pdf

Samsuddin, A., Meor Ruslan, M.I., Abd Halim, A., Zahari, N.F., \& Mohamad Fazi, N.F. (2014). Educators' awareness and acceptance towards Goods and Services Tax (GST) implementation in Malaysia: A study in Bandar Muadzam Shah, Pahang. International Journal of Business, Economics and Law, 4(1), 1-10.

Sandford, C. (1995). Tax compliance costs measurement and policy. (p.379). Fiscal Publications, Bath. 
Sekaran, U., \& Bougie, R. (2009). Research methods for business a skill building approach (Fifth Edition). UK: John Wiley \& Sons Ltd.

Slemrod, J., \& Venkatesh, V. (2002). The income tax compliance cost of large and mid-size businesses: A Report to the IRS LMSB Division, Office of Tax Policy Research, University of Michigan Business School.

Tran-Nam, B. (2000). The Implementation Costs of the GST in Australia: Concepts, Preliminary Estimates and Implications. Journal of Australian Taxation, 331-343.

Weichenrieder, A.J. (2007). Survey on the taxation of small and medium-sized enterprise: Draft Report on Response to the Questionnaire. Retrieved from http://www.oecd.org/tax/tax-policy/39597756.pdf

Yew, T.E. (2009). When should malaysia implement GST? New Straits Times, p.8.

Yong. S. (2011). Tax compliance and small and medium enterprise operators: An intracultural study in New Zealand. Doctoral Thesis, Auckland University of Technology, New Zealand.

Yong, S., \& Hulst, G. (2014). Multiculturalism and tax compliance of business entrepreneurs. In conference proceeding. Accounting and Finance Association of Australia and New Zealand. Auckland, New Zealand.

Zhou, L.Z., Tam, J., \& Heng-Contaxis, J. (2013). The introduction of Goods and Services Tax in Malaysia: A policy analysis. Centre for Public Paper Series Asian Strategy \& Leadership Institute, 1-29. 